\title{
Articles
}

\section{Parallel insulin resistance and beta cell decompensation in Type 2 diabetes}

\author{
D. Tripathy ${ }^{1}$ K. F. Eriksson ${ }^{1}$ M. Orho-Melander ${ }^{1}$ - J. Fredriksson ${ }^{1}$ • G. Ahlqvist ${ }^{1} \cdot$ L. Groop $^{1,2}$ \\ ${ }^{1}$ Wallenberg Laboratory, Department of Endocrinology, Lund University, Sweden \\ ${ }^{2}$ Department of Endocrinology, Malmö University Hospital, Lund University, Malmö, Sweden
}

\section{Abstract}

Aims/hypothesis. The aim of the study was to evaluate the relationship between insulin sensitivity, beta cell function and glucose tolerance, and its dependence on variants in the newly identified Type 2 diabetes susceptibility gene, calpain-10 (CAPN10).

Methods. We studied 203 men of the same age but with varying degrees of glucose tolerance. These men participated in (i) an oral glucose tolerance test, (ii) a euglycaemic clamp combined with indirect calorimetry and infusion of $\left[3-{ }^{3} \mathrm{H}\right]$-glucose and (iii) a stepwise assessment of acute insulin response to arginine (AIR) at three different glucose concentrations (fasting, 14 and $28 \mathrm{mmol} / \mathrm{l})$.

Results. There was a linear increase in NEFA levels $(p<0.0005)$ and WHR $(p<0.0005)$ and decrease in glucose uptake due to a reduction in glucose storage over the entire range of glucose tolerance $(r=-0.404$; $p<0.005)$. No increase in endogenous glucose production (EGP) was seen until patients had manifest diabetes. However, when EGP was expressed relative to fasting insulin concentrations, there was a linear deterioration of basal hepatic insulin sensitivity ( $r=$ $-0.514 ; p<0.005)$. The AIR followed a bell-shaped curve with an initial rise and subsequent decrease. However, AIR adjusted for insulin sensitivity (disposition index) showed a linear decrease with increasing glucose concentrations $(r=-0.563 ; p<0.001)$ starting already in subjects with normal glucose tolerance. There was an inverse correlation between increase in WHR and NEFA and peripheral as well as hepatic insulin sensitivity. Subjects with the genotype combination of CAPN10 consisting of SNP44 TT and SNP43 $G G$ genotypes had significantly lower insulin-stimulated glucose uptake than carriers of the other genotype combinations $(5.3 \pm 0.4$ vs $7.2 \pm 0.4 \mathrm{mg} \cdot \mathrm{ffm} \mathrm{kg}-1$ $\left.\mathrm{min}^{-1} \cdot \mathrm{mU} \cdot 1^{-1} ; p<0.005\right)$.

Conclusions/interpretation. We conclude that the prediabetic state is characterised by a similar linear deterioration of peripheral and hepatic insulin sensitivity as beta cell function and that variants in the CAPN1O gene modify this relationship. These findings are compatible with a common defect in muscle, liver and beta cells in the pathogenesis of Type 2 diabetes.

Keywords Beta cell function - Calpain-10 gene · Disposition index - Endogenous glucose production Glucose tolerance $\cdot$ Hepatic insulin sensitivity · Insulin resistance $\cdot$ Insulin secretion · Type 2 Diabetes
Received: 26 August 2003 / Accepted: 19 January 2004 Published online: 28 April 2004

(C) Springer-Verlag 2004

L. Groop ( $)$

Department of Endocrinology, Malmö University Hospital, Lund University, 20502 Malmö, Sweden

E-mail: leif.groop@endo.mas.lu.se

Tel.: +46-40-332303, Fax: +46-40-337023

Abbreviations: AIR, acute insulin responses to arginine . DI, disposition index · EGP, endogenous glucose production · $\mathrm{ffm}$, fat free mass $\cdot \mathrm{VO}_{2 \max }$, maximal aerobic capacity

\section{Introduction}

Type 2 diabetes is characterised by a combination of at least three defects including beta cell dysfunction, skeletal muscle insulin resistance and increased endogenous glucose production (EGP) $[1,2]$. The precise mechanisms by which these three factors interact to produce impaired glucose tolerance and diabetes are uncertain. Neither is it known whether one defect is the consequence of the other(s) or whether they have a common causative mechanism. If all three de- 
fects were manifested at the same time, this could support the common mechanism hypothesis. At present, there is little support for this. The only prospective study including sequential estimates of beta cell function, insulin sensitivity and EGP in a small number of Pima Indians showed that impaired insulin sensitivity occurred very early in the pre-diabetic state, whereas failure of the pancreatic beta cells to compensate for insulin resistance occurred later, but preceded manifestation of diabetes [3]. These data are compatible with cross-sectional data from larger studies in Pima Indians and white people of European extraction [4, 5]. The role of an increased rate of EGP in the pre-diabetic state is controversial. In most studies, including the one on Pima Indians, enhanced EGP has been a relatively late event $[3,6,7,8,9]$. However, as EGP is extremely sensitive to insulin [10], normal rates of EGP in the face of fasting hyperinsulinaemia could be a sign of hepatic insensitivity to insulin.

One explanation for these inconsistencies is the lack of large studies applying concomitant comprehensive measures of all three defects. Whereas the euglycaemic-hyperinsulinaemic clamp is the gold standard for the assessment of whole-body insulin sensitivity, there is less agreement about the gold standard for estimation of beta cell function. Importantly, most studies have not considered that the insulin response to different stimuli is influenced by the degree of insulin resistance [11]. Ideally these questions should be addressed in a prospective study, but this may not be feasible in a large number of subjects. As the best compromise, we measured beta cell function (acute insulin response to arginine at three different glucose concentrations), whole-body glucose metabolism (hyperinsulinaemic-euglycaemic clamp combined with indirect calorimetry) and EGP (infusion of $\left[3-{ }^{3} \mathrm{H}\right]$ glucose) in 203 non-obese (BMI $26 \mathrm{~kg} / \mathrm{m}^{2}$ ) Swedish white men. These men, from the Malmö Prospective Study, were of a similar age (66 years) but had varying degrees of glucose tolerance.

The Malmö study was started in 1974 as an intervention project to prevent Type 2 diabetes in men born between 1926 and 1935 [12,13]. At inclusion all men had normal glucose tolerance but during follow-up some of them developed impaired glucose tolerance or Type 2 diabetes [13].

There is considerable evidence that genetic factors increase the risk for Type 2 diabetes. Recently, the calpain-10 gene (CAPN1O) on chromosome 2 was identified by positional cloning as a potential candidate gene for Type 2 diabetes [14, 15]. We therefore also studied whether variants in this gene would modify insulin sensitivity and beta cell function.

\section{Subjects and methods}

Subjects. All subjects underwent four different procedures: (i) an oral glucose tolerance test; (ii) a bicycle ergometer test for the estimation of maximal aerobic capacity $\left(\mathrm{VO}_{2 \max }\right.$; (iii) a euglycaemic clamp combined with indirect calorimetry and infusion of $\left[3-{ }^{3} \mathrm{H}\right]$-glucose to quantify glucose metabolism and EGP; and (iv) measurement of acute insulin responses to arginine (AIR) at three different glucose concentrations. All participants had a thorough medical evaluation, including documentation of their medical history, a physical examination and routine laboratory tests. Subjects were classified into different stages of glucose tolerance based upon fasting and 2-hour glucose values during an OGTT. Glucose tolerance was stratified into sixtiles of fasting plasma glucose (3.8-5.3, 5.4-5.6, $5.7-6.1,6.2-6.9,7.0-9.7,9.8-20.8 \mathrm{mmol} / \mathrm{l})$ or sixtiles of 2-hour glucose values during the OGTT (3.4-6.6, 6.7-7.4, $7.5-8.7,8.8-11.0,11.1-16.7,16.8-22.4$ mmol/1) (see Appendix). At inclusion in the study, subjects were classified according to the earlier WHO criteria [16], whereby 72, 63 and 68 subjects respectively had normal glucose tolerance, IGT and diabetes. Using the new ADA/WHO criteria for classification of glucose tolerance [17], 69 had normal glucose tolerance (fasting plasma glucose $<6.1 \mathrm{mmol} / 1$ and 2-hour glucose $<7.8 \mathrm{mmol} / \mathrm{l}$ ), $52 \mathrm{had}$ impaired glucose tolerance, i.e. fasting hyperglycaemia or IGT (fasting plasma glucose 6.1$6.9 \mathrm{mmol} / \mathrm{l}$ and/or 2-hour glucose value 7.8-11.1 $\mathrm{mmol} / \mathrm{l}$ ), whereas 82 subjects had manifest Type 2 diabetes (fasting plasma glucose $>7.0 \mathrm{mmol} / \mathrm{l}$ and/or 2-hour glucose $>11.1 \mathrm{mmol} / \mathrm{l})$. Of the subjects with diabetes, 15 were diagnosed during the OGTT, 35 were being treated by diet alone, 15 with glibenclamide (glyburide), 11 with glibenclamide and metformin, and six with insulin and/or glibenclamide / metformin. The study protocol was approved by the Lund University ethics committee and all subjects gave informed consent.

Anthropometric measurements. Height, weight, waist to hip ratio and fat free mass were measured on the day of the euglycaemic clamp. As an estimate of abdominal obesity we also used another index, waist/height ${ }^{2}$, referred to as the waist index. The fat free mass was measured by a bioelectrical impedance method using a two-terminal portable impedance analyser (BIA 101, RJL, Akern, Copenhagen, Denmark) [18].

Oral glucose tolerance test. A 2-hour glucose tolerance test using $75 \mathrm{~g}$ of glucose was performed after overnight fasting. Venous samples for measurement of glucose and insulin concentrations were collected at 0,40 and 120 min after the glucose load.

Maximal aerobic capacity. Maximal oxygen uptake was measured using an incremental work-conducted upright exercise test on a bicycle ergometer (Monark, Varberg, Sweden) combined with continuous analysis of expiratory gases. Exercise was started at a workload varying from 30 to $100 \mathrm{~W}$, depending on the previous history of endurance training or exercise habits, and then increased by 20 to $50 \mathrm{~W}$ every $3 \mathrm{~min}$, until a perceived exhaustion or a respiratory quotient of 1.0 was reached. We defined $\mathrm{VO}_{2 \max }$ as the value measured during the last 30 seconds of the exercise test and it is expressed per lean body mass.

Peripheral and hepatic insulin sensitivity. Insulin sensitivity was determined with the standard euglycaemic-hyperinsulinaemic clamp [19] combined with infusion of $\left[3-{ }^{3} \mathrm{H}\right]-$ glucose and indirect calorimetry. The subjects came to the clin- 
ical research centre after an overnight fast. A constant $\left(0.003 \mathrm{MBq} \cdot \mathrm{m}^{-2} \cdot \mathrm{min}^{-1}\right)$ intravenous infusion of $\left[3-{ }^{3} \mathrm{H}\right]$-glucose (Amersham International, Little Chalfont, UK) was started and continued throughout the study. At the start of this infusion a priming dose of $\left[3-{ }^{3} \mathrm{H}\right]$-glucose $\left(0.31 \mathrm{MBq} / \mathrm{m}^{2}\right)$ was injected. In a subset of patients $(n=8),\left[3-{ }^{3} \mathrm{H}\right]$ glucose was added to the glucose infusate (hot glucose technique) to maintain plasmaspecific activity at the basal level during the clamp. Labelling of the glucose infusion was based upon previous estimates of the expected glucose infusion and EGP rate during the clamp [20]. Blood samples were collected at timed intervals in fluoride-treated tubes for the determination of plasma-glucose- and plasma- $\left[3-{ }^{3} \mathrm{H}\right]$ glucose-specific activity. After a 150 -min tracer equilibration period, a primed-constant infusion of insulin (Actrapid Human,100 U/ml: Novo Nordisk, Gentofte, Denmark) at a constant infusion rate of $45 \mathrm{mU} / \mathrm{m}^{2}$ was started and continued for 120 minutes. A variable infusion of $20 \%$ glucose was started to maintain plasma glucose concentration unchanged at $5.5 \mathrm{mmol} / \mathrm{l}$ for 120 minutes. Plasma glucose was measured at 5-minute intervals. The mean $\mathrm{CV}$ for glucose values during the clamp was $6.3 \%$. Subjects taking insulin continued to do so until the night prior to the study.

Indirect calorimetry. This was performed in order to estimate the substrate oxidation rates $45 \mathrm{~min}$ before the start of the clamp and during the last $45 \mathrm{~min}$ of the clamp. It was done using a computerised open-circuit system for measuring the gas exchange across a canopy (Deltatrac; Datex Instruments, Helsinki, Finland). From the measurement of gas exchange, energy expenditure and the respiratory exchange rate were calculated. Rates of lipid and glucose oxidation were derived from indirect calorimetry after correction for protein oxidation, which was estimated from the urinary excretion of urea.

Calculations. Basal EGP was calculated by dividing the $\left[3-{ }^{3} \mathrm{H}\right]$ glucose infusion rate by the steady-state plateau of glucose-specific activity in plasma during the last $30 \mathrm{~min}$ of the basal tracer infusion period. During administration of insulin and glucose a non-steady-state condition in plasma $\left[3-{ }^{3} \mathrm{H}\right] \mathrm{glu}-$ cose exists. At high rates of glucose uptake the classical model of Steele is known to produce negative estimates of EGP. By adding $[3-3 \mathrm{H}]$ glucose to the variable exogenous glucose infusion, the plasma $\left[3-{ }^{3} \mathrm{H}\right]$ glucose-specific activity was maintained constant in a subset of subjects with normal glucose tolerance $(n=8)$, while others had cold glucose infusions. In eight subjects with normal glucose tolerance who underwent the hot glucose protocol for estimation of EGP, basal EGP was not different from that seen using the cold glucose method $(2.7 \pm 0.05$ vs $\left.2.8 \pm 0.1 \mathrm{mg} \cdot \mathrm{ffm} \mathrm{kg}-1 \cdot \mathrm{min}^{-1}, p=\mathrm{NS}\right)$. Only two of the eight subjects had negative estimates of EGP during the clamp. Thus EGP during the clamp was significantly higher when the hot glucose method was used than when the cold glucose method was used. However, the values were close to zero, supporting the view that EGP during the clamp is completely suppressed $\left(0.01 \pm 0.2 \mathrm{vs}-0.8 \pm 0.19 \mathrm{mg} \cdot \mathrm{ffm} \mathrm{kg} \mathrm{kg}^{-1} \cdot \mathrm{min}^{-1}, p=0.01\right)$. The infusion rate of exogenous glucose was integrated over 20 -min intervals and subtracted from the total rate of glucose appearance to obtain the rate of residual EGP during the clamp. The negative EGP values seen in the insulin-stimulated state were adapted as zero in calculations. Total body glucose metabolism was calculated by adding the mean rate of EGP (if a positive number) during the last $60 \mathrm{~min}$ of the insulin clamp to the glucose infusion rate during the same period (M-value). Insulin sensitivity was also calculated as the ratio of glucose uptake and mean steady-state insulin concentrations during the last 60 min of the clamp $\left(\mathrm{M} / \mathrm{I}_{\text {clamp }}\right)$. Non-oxidative glucose metabo- lism, mainly storage of glucose as glycogen, was calculated as the difference between glucose metabolism and glucose oxidation, as determined by indirect calorimetry. Net rates of glucose and lipid oxidation were calculated from indirect calorimetric measurements in the basal state and during the last $60 \mathrm{~min}$ of the insulin clamp. Protein oxidation was calculated from overnight urinary urea nitrogen excretion, collected overnight and during the insulin clamp.

Blood samples for measurements of serum insulin and $\left[3-{ }^{3} \mathrm{H}\right]$ glucose-specific activity were drawn every $30 \mathrm{~min}$, while samples for the measurement of NEFA were collected at $-10,0,110$ and $120 \mathrm{~min}$ during the clamp. Samples for NEFA were collected in pre-chilled tubes to prevent in vitro lipolysis [21].

Beta cell function. Insulin secretion was measured with i.v. arginine stimulation at three different plasma glucose levels (fasting, 14 and $28 \mathrm{mmol} / \mathrm{l}$ ) [22, 23]. Baseline samples were collected at -5 and $-2 \mathrm{~min}$. A maximally stimulating dose of arginine hydrochloride $(5 \mathrm{~g})$ was then injected i.v. over $45 \mathrm{sec}-$ onds. Samples for insulin were collected at 2, 3, 4 and 5 min. A variable infusion of $20 \%$ glucose was then started, to raise and maintain plasma glucose at 13 to $15 \mathrm{mmol} / \mathrm{l}$ for 20 to $25 \mathrm{~min}$. New baseline samples were collected and then arginine (5 g) was again injected and samples were collected at 2 , 3,4 and $5 \mathrm{~min}$. After this second step a 2.5 -hour resting period followed, to avoid the priming effect of hyperglycaemia on the last step [24]. After the resting period, baseline samples were again collected and another glucose infusion was started to raise the plasma glucose concentration to levels over $25 \mathrm{mmol} / \mathrm{l}$. At this plasma glucose level, new baseline samples were taken and arginine ( $5 \mathrm{~g}$ ) was injected, followed by the collection of final samples at 2, 3, 4 and $5 \mathrm{~min}$. The AIR were calculated as the mean of the +2 to +5 min samples minus the mean pre-stimulus sample (mean of -5 and $-2 \mathrm{~min}$ ). The slope between the AIR at fasting glucose and at plasma glucose of $14 \mathrm{mmol} / \mathrm{l}$ (slope $\mathrm{AIR}=\Delta \mathrm{AIR} / \Delta$ glucose) was calculated as a measure of glucose potentiation of beta cell secretion. The AIR at the highest glucose level $\left(\mathrm{AIR}_{\max }>25 \mathrm{mmol} / \mathrm{l}\right)$ was taken as a measure of the maximal insulin secretory capacity of the beta cells.

To quantify the relation between insulin sensitivity and insulin secretion, we also calculated the product of insulin sensitivity and the AIR, which is also called the disposition index $[11,25]$. This product was termed the disposition index (or compensation index) and measures the ability of the individual to adapt his or her insulin secretion to the prevailing insulin sensitivity.

Genotyping of CAPN10 SNP-43 (G/A) and SNP-44 (T/C). The two CAPN10 SNPs were genotyped using the Multiplex SNaPshot kit (Applied Biosystems, Foster City, Calif., USA) for single base pair extension on ABI3100 (Applied Biosystems). A 476-bp fragment containing both CAPN10 SNPs was amplified with primers 5'-GCTGGCTGGTGACATCAGTGC-3' and 5'TCAGGTTCCATCTTTCTGCCAG-3'. Template PCR was carried out using the AccuPrime Taq DNA Polymerase system (Invitrogen, Lidingö, Sweden) in a volume of $12.5 \mu \mathrm{l}$ containing $1 \times$ PCR Buffer II (provided in the kit), $4.5 \mathrm{mmol} / 1 \mathrm{MgCl}_{2}$, $2.5 \mathrm{pmol}$ of each primer and $25 \mathrm{ng}$ genomic DNA. The cycling conditions were $94{ }^{\circ} \mathrm{C}$ for $2 \mathrm{~min}, 35$ cycles of $94{ }^{\circ} \mathrm{C}$ for $30 \mathrm{~s}$, $64{ }^{\circ} \mathrm{C}$ for $30 \mathrm{~s}$ and $68{ }^{\circ} \mathrm{C}$ for $60 \mathrm{~s}$. Before single base pair extension, PCR samples were treated with Shrimp Alkaline Phosphatase (SAP) (Amersham Biosciences, Uppsala, Sweden) and Exonuclease I (MBI Fermentas, Vilnius, Lithuania). Single base pair extension PCR reactions were performed according to the manufacturer's instructions with detection primers: $5^{\prime}$ - 
GGCTTAGCCTCACCTTCAAA-3' for CAPN10 SNP-43 and 5'-GACTGCAGGGCGCTCACGCTTGCTG-3' for CAPN10 SNP-44. Before analysis on the ABI3100, the samples were once again treated with Shrimp Alkaline Phosphatase. Genotypes were analysed using the GeneMapper 2.0 software (Applied Biosystems).

Assays. Blood glucose concentrations were measured in duplicate on a glucose analyser (Beckman glucose analyzer II, Beckman instruments, Fullerton, Calif., USA). Plasma insulin concentrations were measured with a double antibody ELISA (DAKO, Cambridgeshire, UK) using an interassay $\mathrm{CV}$ of $7 \%$ and an intra-assay $\mathrm{CV}$ of $7.5 \%$. NEFA were measured using an enzymatic colorimetric ACS-ACOD-MEHA method (Wako Chemicals, Neuss, Germany) with an intra-assay CV of $10.8 \%$ and an interassay $\mathrm{CV}$ of $5.7 \%$. [3-3 $\mathrm{H}]$ Glucose-specific activity was measured in duplicate from the supernatant of $0.5 \mathrm{~mol} / \mathrm{l}$ perchloric acid extract of samples after evaporation of radiolabelled water. Serum and urinary urea were measured through oxidation of NADH to NAD by spectrophotometry at $340 \mathrm{~nm}$ (Synchron LX System Chemistry Information, Synchhron LX 20, Beckman Coulter, Palo Alto, Calif., USA).

Statistical analysis. Data are expressed as means \pm SD or means \pm SEM as indicated. Plasma insulin and glucose values were log transformed to improve skewness and kurtosis. Differences between the groups were tested by Student's $t$ test and by ANOVA after adjustment for BMI. Analysis for linear trend was carried out by ANOVA. Multiple regression analysis was carried out with fasting and 2-hour glucose as dependent variables and measures of insulin secretion and insulin action, and with age and BMI as independent variables. The significance of relationships between variables was tested using Pearson's or Spearman's correlation coefficients where applicable. A $p$ value of less than 0.05 was considered statistically significant. Data were analysed using Number Cruncher Statistical System (NCSS, version 6.0, Statistical solutions, Cork, Ireland).

\section{Results}

Anthropometric and metabolic characteristics. Table 1 shows the clinical characteristics of the subjects in relation to sixtiles of fasting plasma glucose. Data in relation to sixtiles of 2 -hour glucose are provided in the Appendix. The BMI $(r=0.213 ; p=0.002)$, WHR $(r=0.256 ; p=0.0003)$ and waist index $(r=0.219$; $p=0.002)$ increased progressively from the lowest to the highest sixtile of fasting plasma glucose (Fig. 1). However, no difference was seen in the fat free mass between subjects in different glucose sixtiles. The fasting NEFA concentrations increased progressively with worsening of glucose tolerance $(r=0.344$; $p<0.0005)$. The NEFA concentrations were less suppressed by insulin in the highest than in the lowest sixtile $(p<0.05)$.

There was a progressive increase in fasting insulin concentrations with increasing fasting plasma glucose sixtiles $(r=0.426 ; p<0.0005)$, whereas the 2 -hour insu-

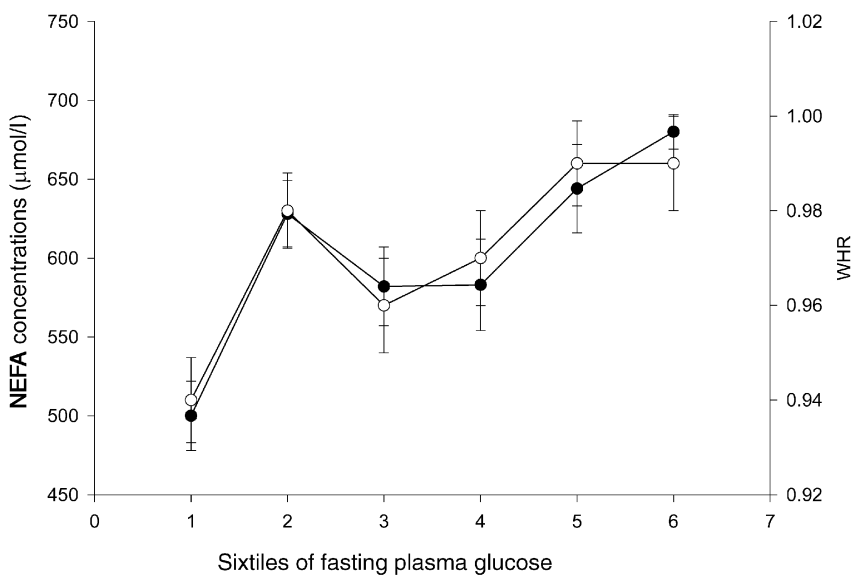

Fig. 1. Fasting NEFA concentrations (closed circles) and WHR (open circles) in relation to sixtiles of fasting plasma glucose in 203 men. Sixtiles are shown as median [inter-quartile range]: 1st sixtile: 5.1 [4.7-5.2] mmol/l, 2nd sixtile: 5.5 [5.4-5.6] mmol/1, 3rd sixtile: 5.9 [5.9-6.1] mmol/1, 4th sixtile: 6.4 [6.3-6.7] mmol/l, 5th sixtile : 7.7 [7.4-8.9] mmol/l, 6th sixtile: 12.5 [10.9-16.2] mmol/1

Table 1. Clinical characteristics of the 203 men from the different sixtiles of fasting plasma glucose

\begin{tabular}{|c|c|c|c|c|c|c|}
\hline \multirow[b]{2}{*}{$\begin{array}{l}\text { Fasting plasma glucose }(\mathrm{mmol} / \mathrm{l}) \\
\text { median [interquartile range] }\end{array}$} & \multicolumn{6}{|c|}{ Sixtiles 1 to 6 (left to right) } \\
\hline & $5.1[4.7-5.2]$ & $5.5[5.4-5.6]$ & $5.9[5.9-6.1]$ & $6.4[6.3-6.7]$ & 7.7 [7.4-8.9] & 12.5 [10.9-16.2] \\
\hline Number & 34 & 34 & 34 & 34 & 34 & 33 \\
\hline Age (years) & $66.3 \pm 0.3$ & $65.6 \pm 0.2$ & $66.1 \pm 0.3$ & $65.9 \pm 0.4$ & $65.2 \pm 0.4$ & $66.1 \pm 0.3$ \\
\hline BMI $\left(\mathrm{kg} / \mathrm{m}^{2}\right)$ & $24.9 \pm 0.5$ & $27.5 \pm 0.6^{\mathrm{a}}$ & $26.7 \pm 0.5$ & $26.6 \pm 0.7$ & $27.9 \pm 0.5^{\mathrm{a}}$ & $27.5 \pm 0.7^{\mathrm{a}}$ \\
\hline $\mathrm{WHR}^{\mathrm{b}}$ & $0.94 \pm 0.01$ & $0.98 \pm 0.01$ & $0.96 \pm 0.02$ & $0.97 \pm 0.02$ & $0.98 \pm 0.01^{\mathrm{a}}$ & $0.99 \pm 9.01^{\mathrm{a}}$ \\
\hline Waist index (waist/height ${ }^{2}$ ) & $29.8 \pm 0.7$ & $32.3 \pm 0.6$ & $31.5 \pm 0.5$ & $31.7 \pm 0.7$ & $33.1 \pm 0.7^{\mathrm{a}}$ & $32.8 \pm 0.7^{\mathrm{a}}$ \\
\hline $\mathrm{VO}_{2 \max } \mathrm{ml} \cdot \mathrm{ffm} \mathrm{kg}{ }^{-1} \cdot \mathrm{min}^{-1}$ & $37.8 \pm 1.2$ & $34.2 \pm 1.4$ & $39.2 \pm 1.2$ & $35.1 \pm 1.4$ & $34.3 \pm 1.5$ & $30.3 \pm 1.4^{\mathrm{a}}$ \\
\hline 2-h plasma glucose $(\mathrm{mmol} / \mathrm{l})$ & $6.8 \pm 0.3$ & $7.6 \pm 0.3$ & $7.8 \pm 0.3$ & $10.1 \pm 0.5$ & $12.6 \pm 0.7$ & $19.4 \pm 0.5$ \\
\hline $\mathrm{HbA}_{1} \mathrm{c}(\%)$ & $4.8 \pm 0.08$ & $4.8 \pm 0.09$ & $4.9 \pm 0.08$ & $5.4 \pm 0.2^{\mathrm{a}}$ & $6.1 \pm 0.2^{\mathrm{a}}$ & $8.2 \pm 0.3^{\mathrm{a}}$ \\
\hline Fasting insulin $\left(\mathrm{mU} / \mathrm{l}^{\mathrm{b}}\right.$ & $7.5 \pm 0.8$ & $10.15 \pm 1.0$ & $11.1 \pm 1.0 .9$ & $17.4 \pm 2.9$ & $16.4 \pm 1.9$ & $14.5 \pm 1.3$ \\
\hline 2-h insulin (mU/l) & $58.5 \pm 9.6$ & $75.1 \pm 8.9$ & $66.4 \pm 6.6$ & $91.8 \pm 9.4$ & $74.3 \pm 10.8$ & $25.6 \pm 2.2$ \\
\hline Cholesterol (mmol/l) & $5.5 \pm 0.1$ & $5.6 \pm 0.1$ & $5.6 \pm 0.2$ & $5.5 \pm 0.2$ & $5.9 \pm 0.1$ & $5.7 \pm 0.2$ \\
\hline HDL cholesterol $(\mathrm{mmol} / \mathrm{l})$ & $1.27 \pm 0.05$ & $1.2 \pm 0.05$ & $1.2 \pm 0.056$ & $1.15 \pm 0.05$ & $1.15 \pm 0.04$ & $1.07 \pm 0.06$ \\
\hline Triglycerides $^{\mathrm{b}}(\mathrm{mmol} / \mathrm{l})$ & $1.29 \pm 0.1$ & $1.45 \pm 0.2$ & $1.32 \pm 0.08$ & $1.66 \pm 0.2$ & $1.98 \pm 0.2$ & $2.57 \pm 0.3^{\mathrm{a}}$ \\
\hline
\end{tabular}

Data are means \pm SEM. ${ }^{\mathrm{a}} p<0.05$ vs lowest sixtile, ${ }^{\mathrm{b}} p<0.05$ for trend. $\mathrm{VO}_{2 \max }$, maximal aerobic capacity 
lin concentration followed a bell-shaped curve, with the highest values seen in the fourth sixtile (fasting plasma glucose $\sim 6.5 \mathrm{mmol} / \mathrm{l}$ ).

$\mathrm{VO}_{2 \text { max }}$ declined progressively with worsening glucose tolerance $(r=-0.228 ; p<0.0005)$, with significantly lower values in subjects in the highest sixtile than in subjects in the lowest sixtile $(p<0.005)$. The fasting plasma glucose $(r=-0.228 ; p<0.0005)$ and 2-hour glucose $(r=-0.314 ; p<0.0005)$ values correlated with $\mathrm{VO}_{2 \max }$

Glucose metabolism. The rate of insulin-stimulated glucose metabolism decreased linearly with increasing fasting plasma glucose $(r=-0.443 ; p<0.005)$ and 2 -hour glucose concentrations $(r=-0.505 ; p<0.005)$. Subjects from the highest sixtile had $\sim 50 \%$ lower



Fig. 2. Contribution of oxidative (black bars) and non-oxidative glucose metabolism (grey bars) to total-body insulinstimulated glucose metabolism in relation to sixtiles of fasting plasma glucose



glucose uptake values than subjects from the lowest sixtile $(3.2 \pm 0.5$ vs $7.5 \pm 0.4, p<0.005)$ (Fig. 2). The reduction in glucose uptake was almost completely accounted for by a decrease in non-oxidative glucose metabolism, which decreased in parallel with glucose uptake $(r=0.381 ; p<0.0005)$. The decrease in nonoxidative glucose metabolism showed an inverse correlation with both fasting plasma glucose $(r=-0.423$; $p<0.0005)$ and 2-hour glucose $(r=-0.465 ; p<0.0005)$. In the insulin-stimulated state, subjects in the highest sixtile of fasting plasma glucose had lower glucose oxidation rates $(p<0.005)$ than subjects in the lowest sixtile, while there was no difference in glucose oxidation rates in the basal state.

Although the basal rate of EGP correlated with fasting plasma glucose $(r=0.338 ; p<0.005)$, it was actually only increased in the highest glucose sixtile (Fig. 3). However, when the prevailing fasting insulin concentration was taken into account (basal hepatic insulin sensitivity; basal EGP/fasting plasma insulin), there was a progressive decline in basal hepatic insulin sensitivity with increasing fasting plasma glucose $(r=-0.415 ; p<0.0005)$. In this case basal hepatic insulin sensitivity correlated with whole-body glucose uptake ( $r=0.746 ; p<0.0005)$. Suppression of EGP during the clamp was complete in all but the last sixtile of glucose.

The rate of lipid oxidation in the basal state and during the clamp was higher in subjects from the highest glucose sixtile than in subjects from the lowest sixtile $(p<0.05)$. Rates of protein oxidation were similar in both the basal and the insulin-stimulated state. In the basal state, the respiratory quotient was not different between the sixtiles. However, during the clamp, subjects in the highest sixtile of fasting plasma glucose had a lower respiratory quotient than subjects in the other groups $(0.88 \pm 0.002$ vs $0.82 \pm 0.02$, $p<0.005)$.

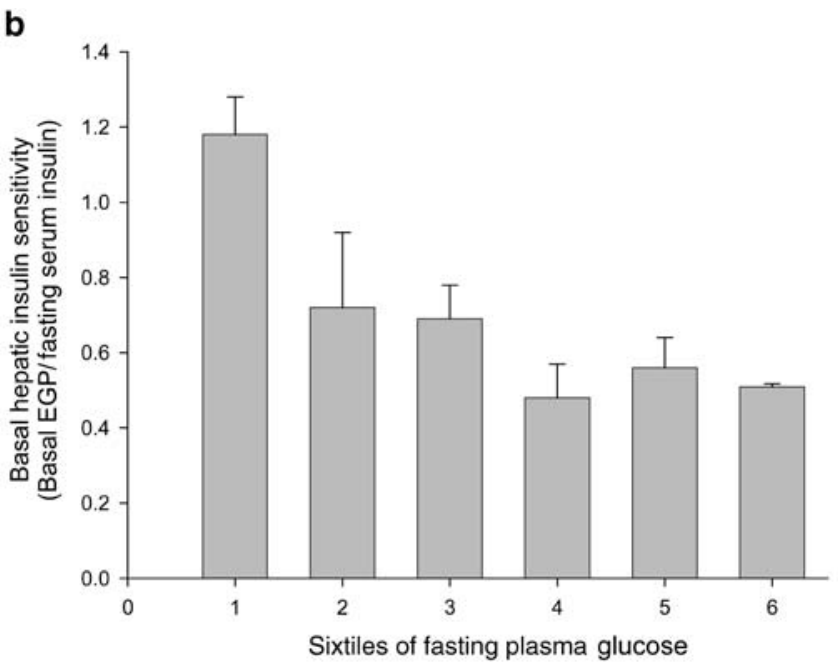

Fig. 3. Rates of endogeneous glucose production rates (EGP) (a) in the basal state (dark bars) and during the hyperinsulinaemic clamp (light bars). b. Basal hepatic insulin sensitivity (EGP/fasting serum insulin) in relation to sixtiles of fasting plasma glucose 



Fig. 4. Acute (2-5 $\mathrm{min})$ insulin response to $5 \mathrm{~g}$ arginine i.v. (2-5-min post-load increase) at basal $\left(\mathrm{AIR}_{\mathrm{basal}}\right)(\mathbf{a})$, at $14 \mathrm{mmol} / \mathrm{l}\left(\mathrm{AIR}_{14}\right)(\mathbf{b})$ and $28 \mathrm{mmol} / \mathrm{l}\left(\mathrm{AIR}_{28}\right)(\mathbf{c})$ of plasma glucose in relation to sixtiles of fasting plasma glucose. d. Glucose potentiation of arginine-induced insulin secretion $\left(\right.$ Slope $\left._{\mathrm{AIR}}\right)$ in relation to sixtiles of fasting plasma glucose. e. Acute insulin response to arginine at $14 \mathrm{mmol} / \mathrm{l}$ of glucose adjusted for insulin sensitivity (disposition index), in relation to sixtiles of fasting plasma glucose

Beta cell function. The pattern of AIR at different glucose sixtiles was similar at basal, 14 and $28 \mathrm{mmol} / \mathrm{l}$ glucose concentrations (Fig. 4). The maximum insulin secretion as estimated from the AIR for $28 \mathrm{mmol} / \mathrm{l}$ was significantly lower in the highest sixtile than in the lowest (Fig. 4, $p<0.005$ ). The glucose potentiation of insulin secretion, measured as a ratio of incremental glucose and the insulin from basal to $14 \mathrm{mmol} / \mathrm{l}$ of glucose (i.e. the slope AIR), was similar in the first three sixtiles, after which it started to decline, being almost undetectable at the highest glucose concentration (Fig. 4d). A cut-off point for decline in AIR appeared to be at a fasting plasma glucose level of about $6.5 \mathrm{mmol} / \mathrm{l}$ and a 2-hour glucose level of about $10 \mathrm{mmol} / \mathrm{l}$. (Fig. 5a, b). Beta cell function related to the degree of insulin sensitivity, i.e. the disposition index (AIR at $14 \mathrm{mmol} / \mathrm{l}$ glucose $\times \mathrm{M}$-value), showed a progressive decline with increasing fasting plasma glucose concentrations $(r=-0.563 ; p<0.005)$ (Fig. $4 \mathrm{e})$. Interestingly, this decline was seen in subjects with glucose concentrations within the normal range.

Correlation between NEFA, WHR and insulin sensitivity and insulin secretion. The NEFA concentrations in 

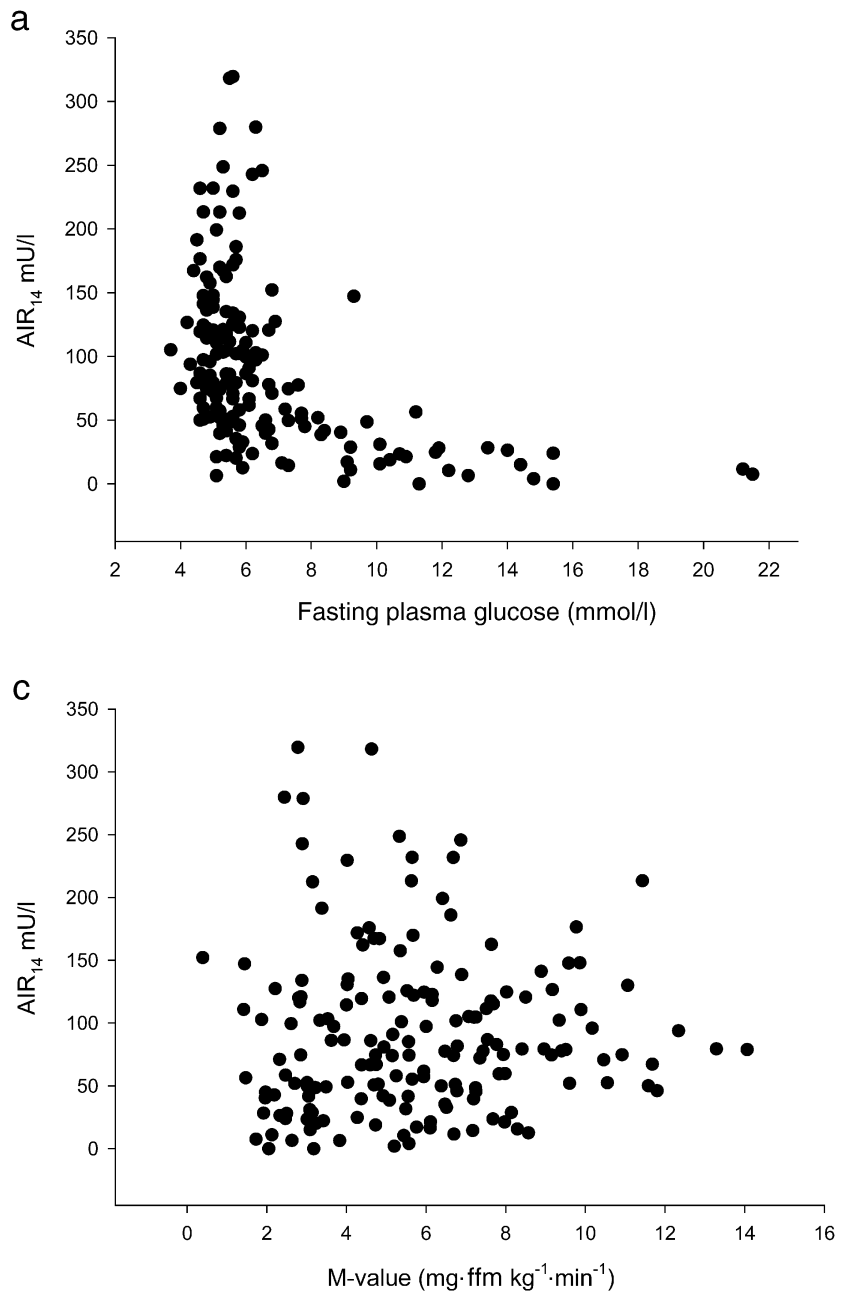

Fig. 5. Relationship between insulin secretion (AIR to arginine at $14 \mathrm{mmol} / \mathrm{l}$ of glucose $\left[\mathrm{AIR}_{14}\right]$ ) and (a) fasting plasma glucose and (b) 2-hour glucose. c. Insulin sensitivity versus insulin secretion. Scatterplot of whole-body insulin sensitivity (M-value) versus AIR to arginine at $14 \mathrm{mmol}$ of glucose $\left(\mathrm{AIR}_{14}\right)$

the fasting state $(r=-0.441 ; p<0.0005)$ and during the euglycaemic clamp $(r=-0.691 ; p<0.0005)$ correlated inversely with whole-body glucose uptake. Similarly, a strong inverse correlation was observed between fasting triglyceride concentrations and the rate of whole-body glucose uptake $(r=-0.463 ; p<0.0005)$. There was a weak inverse correlation between fasting NEFA concentrations and hepatic insulin sensitivity $(r=-0.196 ; p<0.05)$. Both WHR and waist index correlated inversely $(r=-0.431$ and $r=-0.521 ; p<0.005$ for both) with whole-body and $(r=-0.469$ and $r=$ $-0.543 ; p<0.005$ for both) with hepatic insulin sensitivity.

A stepwise multiple regression analysis using insulin sensitivity as a dependent variable and NEFA and AMI as independent variables showed that when NEFA alone was added to the model, it contributed $32 \%$ (increase in multiple $r^{2}$ ) of the variation in

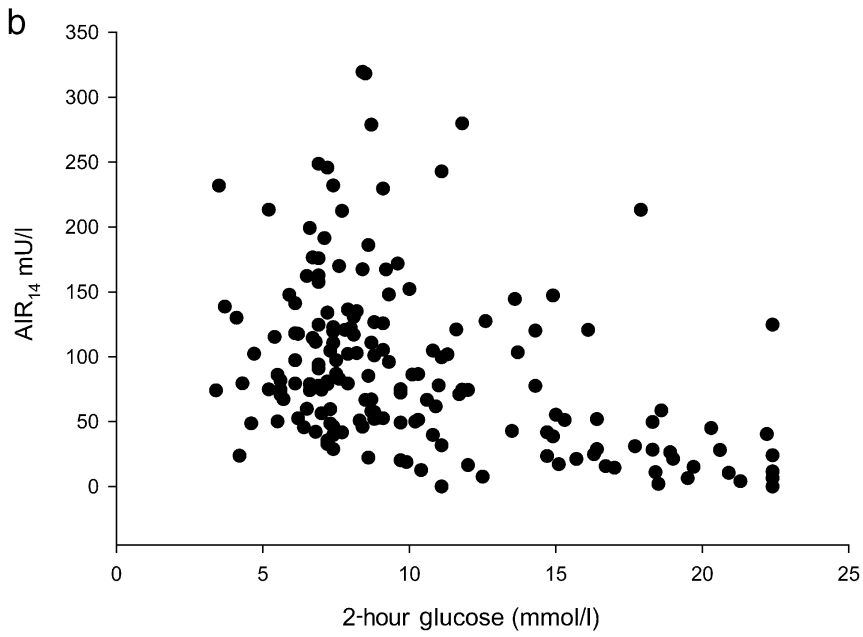

Table 2. Stepwise multiple regression analysis in all subjects, using fasting or 2-h glucose as the dependent variables

\begin{tabular}{|c|c|c|}
\hline & $\begin{array}{l}\text { Partial } \\
\text { correlation } \\
\text { coefficient }\end{array}$ & $\begin{array}{l}\text { Final model } \\
\text { increase* in } \\
\text { multiple } r^{2}\end{array}$ \\
\hline \multicolumn{3}{|l|}{ Fasting plasma glucose } \\
\hline $\begin{array}{l}\text { AIR }_{14} \mathrm{mmol} \\
\text { Basal EGP }\left(\mathrm{mg} \cdot \mathrm{ffm} \mathrm{kg}^{-1} \cdot \mathrm{min}^{-1}\right) \\
\text { M/I }\left(\mathrm{mg} \cdot \mathrm{ffm} \mathrm{kg} \mathrm{kg}^{-1} \cdot \mathrm{min}^{-1} \cdot \mathrm{mIU}^{-1}\right) \\
\text { Multiple } r^{2}\end{array}$ & $\begin{array}{r}-0.151^{\mathrm{b}} \\
0.626^{\mathrm{a}} \\
-0.206^{\mathrm{a}}\end{array}$ & $\begin{array}{l}0.018 \\
0.393 \\
0.042 \\
0.453\end{array}$ \\
\hline \multicolumn{3}{|l|}{ 2-h plasma glucose } \\
\hline $\begin{array}{l}\text { AIR }_{14} \mathrm{mmol} \\
\text { Basal EGP }\left(\mathrm{mg} \cdot \mathrm{ffm} \mathrm{kg}^{-1} \cdot \mathrm{min}^{-1}\right) \\
\text { M/I }\left(\mathrm{mg} \cdot \mathrm{ffm} \mathrm{kg}{ }^{-1} \cdot \mathrm{min}^{-1} \cdot \mathrm{mIU}^{-1}\right) \\
\text { Multiple } r^{2}\end{array}$ & $\begin{array}{r}-0.253^{a} \\
0.499^{a} \\
-0.378^{a}\end{array}$ & $\begin{array}{l}0.052 \\
0.249 \\
0.143 \\
0.444\end{array}$ \\
\hline
\end{tabular}

* Variables included in the multiple regression analysis and their respective contribution to the value of multiple $r^{2}$. ${ }^{\mathrm{a}} p<0.001,{ }^{\mathrm{b}} p<0.05$. AIR, acute insulin responses to arginine; EGP, endogenous glucose production; M/I, mean steady-state insulin concentrations

peripheral insulin sensitivity, and together with waist index it explained $40 \%$ of the variation. To evaluate the contribution of beta cell, liver and muscle to the variations in fasting and 2-hour glucose values, we performed a multiple regression analysis using basal hepatic glucose production, insulin sensitivity and arginine-stimulated insulin secretion at $14 \mathrm{mmol}$ $\left(\mathrm{AIR}_{14}\right)$ as independent variables (Table 2). Totals of $45 \%$ variation in fasting plasma glucose and $44 \%$ in 2-hour glucose levels were explainable by peripheral and hepatic insulin sensitivity and beta cell function.

Metabolic characteristics of subjects in relation to the CAPN10 genotypes and genotype combinations. For CAPN10 SNP43, subjects carrying genotype $G G$ $(n=90)$ were compared with carriers of the genotypes $G A$ or $A A(n=92)$, as the $G$ allele has been associated 
with increased risk of Type 2 diabetes $[15,26]$. In addition, we compared SNP44 TT genotype carriers $(n=124)$ to $T C$ or $C C$ genotype carriers $(n=53)$, and finally, we evaluated the concomitant influence of both SNPs by comparing the genotype combinations SNP44 TT and SNP43 GG $(n=53)$ with those of subjects with other genotype combinations $(n=114)$, as that genotype combination was associated earlier with Type 2 diabetes [26].

No significant differences were observed between carriers of the different CAPN10 SNP-43 or SNP-44 genotypes or $S N P 44 / 43$ genotype combinations regarding age, BMI, WHR, glucose or NEFA concentrations. There was no difference in the prevalence of different genotype combinations when these were compared with different stages of glucose tolerance, e.g. normal glucose tolerance, IFG/IGT and diabetes mellitus. Insulin secretion measured as $\mathrm{AIR}_{14}(101 \pm 8$ vs $80 \pm 7 \mathrm{mIU} / 1, p=0.04)$ and maximal insulin secretion $\left(\mathrm{AIR}_{28}\right)(174 \pm 16$ vs $121 \pm 11 \mathrm{mIU} / \mathrm{l}, p=0.008)$ were higher in subjects with the $G G$ genotype than in subjects with the GA/AA genotypes. This difference disappeared after adjusting for the degree of insulin resistance using the disposition index. No difference was observed between the genotypes with respect to whole-body $\left(6.4 \pm 0.4\right.$ vs $6.8 \pm 0.4 \mathrm{mg} \cdot \mathrm{ffm} \mathrm{kg}^{-1} \cdot \mathrm{min}^{-1}$, $p=\mathrm{NS}$ ) or hepatic insulin sensitivity or the disposition index.

Subjects carrying both risk genotypes, i.e. those who had both SNP44 TT and SNP43 GG genotypes, had a significantly reduced rate of insulin-stimulated glucose metabolism $(5.5 \pm 0.4$ vs $7.1 \pm 0.4, p<0.005)$ compared with subjects with other genotype combinations (Fig. 7). No significant differences were observed in beta cell function or EGP between carriers of the different genotype combinations. Neither were there any significant differences between the two groups with regard to fasting glucose, fat free mass, NEFA and the WHR.

Multiple regression analysis using fasting plasma glucose $(p=0.008)$ and NEFA concentrations $(p<0.0005)$ as covariates, showed that $C A P N 10 S N P-44$ was a predictor of insulin sensitivity $(p=0.01)$. Also, when glucose $(p=0.001)$ and NEFA concentrations $(p<0.0005)$ were used as covariates, the high-risk genotype combination of CAPN1O SNP $44 T T$ and SNP $43 G G$ was a strong predictor of total-body insulin sensitivity $(p=0.009)$.

\section{Discussion}

The key finding of the present study was a similar linear decrease in peripheral and hepatic insulin sensitivity and insulin secretion adjusted for insulin resistance (disposition index) with increasing glucose concentrations. These findings were inversely related to increasing measures of abdominal obesity (WHR and waist index) and NEFA concentrations and influenced by variants in the CAPN1O gene. Although the findings do not prove a causal relationship, they point to the possibility of a common defect in target tissues like muscle, liver and islets.

Peripheral insulin sensitivity. With increasing glucose concentrations, there was a progressive decline in insulin-stimulated glucose uptake. Subjects in the highest sixtile with manifest Type 2 diabetes had a $40 \%$ lower rate of insulin-stimulated glucose metabolism than subjects with normal glucose tolerance in the first sixtile. This is consistent with a recent prospective study on Pima Indians, which demonstrated a $31 \%$ decline in insulin sensitivity with progression from normal glucose tolerance to diabetes [3]. In support of earlier findings [27], we observed an inverse correlation between measures of abdominal obesity as WHR $(r=-0.431, p<0.0005)$ or waist index $(r=$ $-0.521, p<0.0005)$ and glucose metabolism. In addition, there was an inverse correlation between NEFA and triglyceride concentrations and insulin-stimulated glucose uptake $(p<0.0005)$. The question arises as to whether these findings represent only coincidental changes or are causally related. Obesity, particularly abdominal obesity as reflected by increased WHR, is associated with elevated NEFA concentrations [28, $29,30]$. NEFA in plasma is mainly derived from intravascular lipolysis of triglyceride-rich lipoproteins by lipoprotein lipase and from lipolysis of adipose tissue triglyceride by hormone-sensitive lipase. After a meal, uptake with subsequent re-esterification in adipose tissue is an important way to buffer excessive fat. It has been suggested that impaired trapping of NEFA by adipose tissue and redistribution to nonadipose tissues like muscle, liver and beta cells is a feature of insulin resistance [31]. Increased intramyocellular lipid concentrations, particularly the longchain acyl-CoA are strongly correlated with impaired insulin-stimulated glucose metabolism [32, 33, 34]. The impairment in glucose uptake is unlikely to be a consequence of the original Randle's cycle, as the rate of glucose oxidation with increasing glucose concentrations was virtually unchanged [28]. Alternatively, it has been suggested that long-chain acyl-CoA esters can activate protein kinase C- $\theta$ which, in turn, can inactivate the insulin signalling cascade through serine/threonine phosphorylation of the insulin receptor and IRS-1 [35, 36]. This would then lead to decreased activation of phosphatidylinositol 3-kinase and reduced insulin-stimulated glucose transport. In keeping with earlier studies, the decrease in glucose metabolism was almost entirely accounted for by the decrease in non-oxidative metabolism [3]. This does not mean a priori that the defect is restricted to glycogen synthesis; any impairment in glucose transport would also be reflected by impaired glycogen synthesis [37]. 


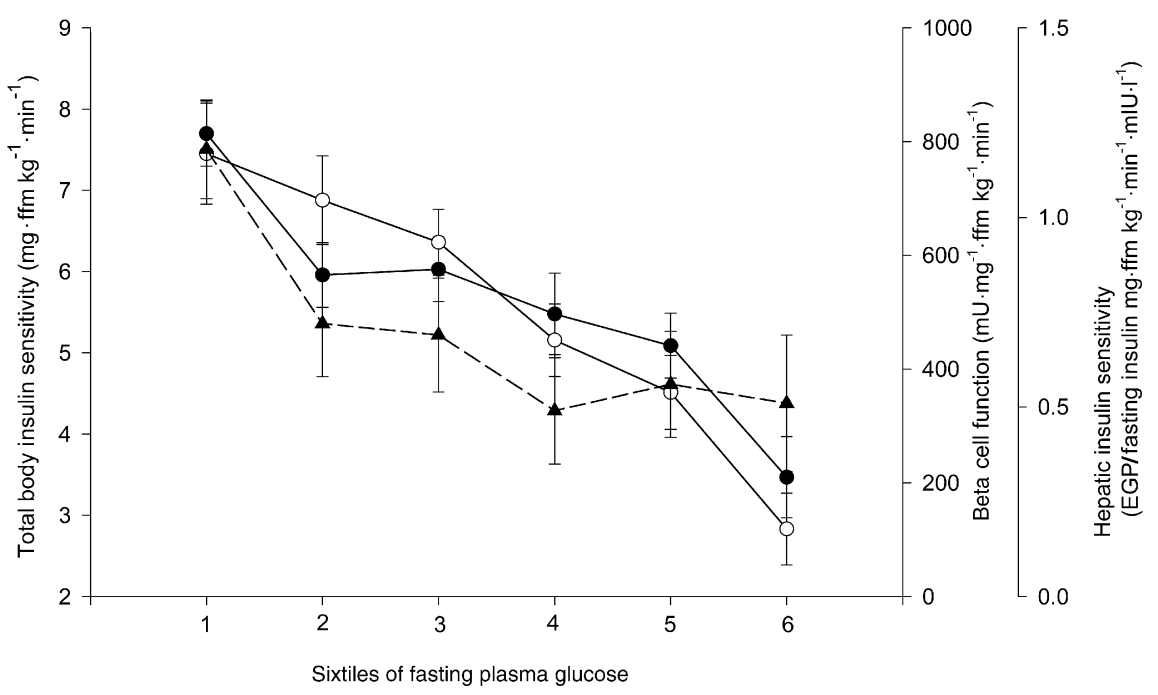

Fig. 6. Total-body insulin sensitivity (closed circles), beta cell function (open circles; expressed as the disposition index) and hepatic insulin sensitivity (closed triangles) in relation to sixtiles of fasting plasma glucose. Endogenous glucose producton (EGP) was corrected for fasting insulin concentrations

Endogenous glucose production. The absolute rate of EGP was increased in the highest glucose sixtile only. This was also associated with impaired suppression of EGP during the clamp. However, when EGP was expressed as hepatic insulin sensitivity by adjusting for the increase in fasting insulin concentrations, there was a linear decrease which paralleled the decrease in insulin-stimulated glucose uptake. This is important as EGP is extremely sensitive to small increases in insulin concentrations with a median effective dose of between 15 and $20 \mathrm{mU} / 1$ [27]. As the fasting insulin concentrations rose from about 7 to $15 \mathrm{mU} / 1$ from the lowest to the highest sixtiles, one would expect complete suppression of basal EGP, if the liver and kidney were normally sensitive to the effects of insulin [38].

The decrease in hepatic insulin sensitivity correlated with the WHR $(r=-0.434 ; p<0.0005)$ and NEFA concentrations $(r=-0.185 ; p<0.05)$. Also, the EGP during the clamp correlated with NEFA concentrations during the clamp $(r=0.349 ; p<0.0005)$. Hyperinsulinaemia in the face of elevated NEFA influx to the liver should lead to increased production of VLDL triglycerides. These particles would not only provide a source of NEFA for peripheral tissues, but could also be deposited in the liver. It has been consistently shown that fat accumulation in the liver is associated with insulin resistance $[38,39]$. It has been suggested that increasing amounts of cytosolic long-chain acyl$\mathrm{CoA}$ in the liver could induce insulin resistance by similar mechanisms to those seen in the muscle, i.e. by influencing the amount of protein kinsase $C-\theta$ [40].

It is also possible that elevated circulating NEFA levels contributed to the elevated insulin levels, as high NEFA levels reduce hepatic insulin extraction
$[41,42]$. Indeed, the fasting NEFA concentrations correlated with the fasting insulin levels $(r=0.263$; $p<0.0005)$. A recent study by Bavenholm et al. on a smaller group of middle-aged Swedish men reported that suppression of EGP was the single most important determinant of glucose intolerance, explaining $55 \%$ of variance in the 2-hour glucose values [43]. Our data are not inconsistent with these findings, although our study was not really designed to assess suppression of EGP during the clamp, as we employed a rather high insulin infusion rate $\left(1 \mathrm{mU} \cdot \mathrm{kg}^{-1} \cdot \mathrm{min}^{-1}\right)$ compared to that used in the study by Bavenholm et al. $\left(0.25 \mathrm{mU} \cdot \mathrm{kg}^{-1} \cdot \mathrm{min}^{-1}\right)$.

Beta cell function. We assessed beta cell function as the AIR at basal, 14 and $28 \mathrm{mmol} / 1$ glucose concentrations. The AIR followed a bell-shaped curve with an initial increase and progressive decline at glucose concentrations compatible with IGT and mild diabetes. Also, the slope of the AIR, i.e. beta cell sensitivity to glucose, followed a similar curve. In addition to glucose, the degree of insulin resistance is a strong determinant of insulin response [11, 25, 44]. Normally beta cells would up-regulate their insulin secretion in the face of insulin resistance. The relationship between insulin secretion and insulin sensitivity can be defined as a hyperbolic function and the product of insulin sensitivity and insulin secretion would equal a constant, the disposition index [25]. As shown above, there was a $40 \%$ decline in insulin sensitivity when moving from the lowest to the highest sixtile of glucose. If we express the insulin response to arginine as a disposition index, we obtain a linear decrease in beta cell function, which is similar to that seen for both peripheral and hepatic insulin sensitivity (Fig. 6). Importantly, this decline starts at slightly elevated glucose concentrations that are still within the normal range. Similarly to the situation in the muscle and the liver, it has been suggested that chronically elevated NEFA can impair glucose-stimulated insulin secretion. In fact there was an inverse relationship between the in- 


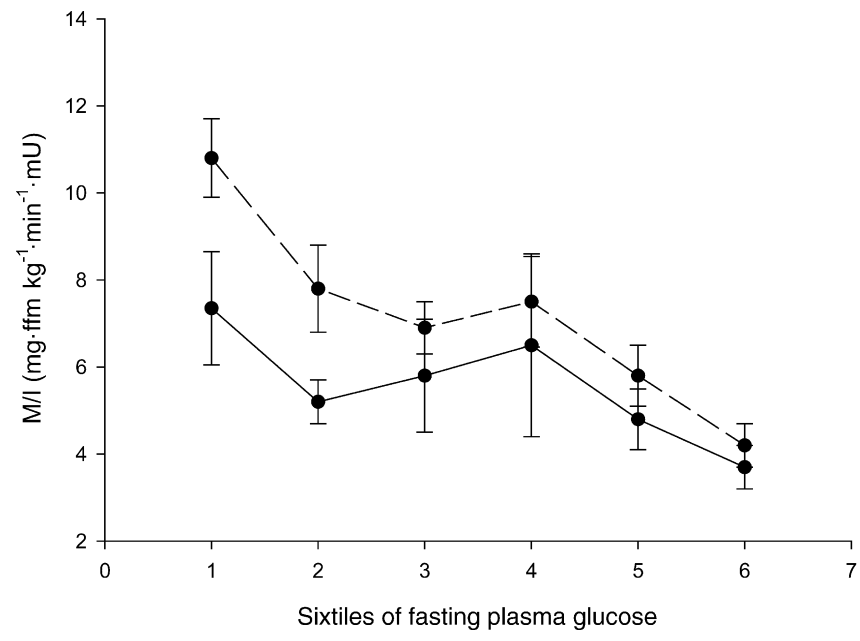

Fig. 7. Insulin-stimulated glucose metabolism in carriers of the genotype combination SNP44 TT and SNP43 GG (unbroken line) and other genotype combinations (broken lines)

crease in serum NEFA concentrations and the decline in the disposition index $(r=-0.326, p<0.0005)$. Most of the data on the putative role of the effect of fat infiltration in the islets on beta cell function have been obtained in experimental animals with a propensity to accumulate triglycerides in their islets, e.g. the ZDF rat [45]. Treatment with thiazolidinediones reduces the amount of fat and enhances insulin secretion in these animals [46]. Nevertheless, there is evidence that human islets increase their fat content with ageing and increasing body weight [47]. It is thus tempting to speculate that mechanisms similar to those used in muscle and liver to handle fat overload are operative in the islets. The enzymatic machinery for lipolysis exists in the islets, including hormone-sensitive lipase [48] and phosphodiesterase 3B [49].

The limitations of this study owing to its crosssectional design also need to be considered. The hypothesis could, however, be tested in a prospective study, in which the increase in NEFA is prevented and peripheral and hepatic insulin sensitivity as well as beta cell function are monitored.

Role of variants in calpain-10 gene. The calpain-10 (CAPN10) gene has emerged as one of the prime candidate genes for Type 2 diabetes during recent years $[14,26,50,51]$. We therefore tested the hypothesis that known variants in two of the most common SNPs (43 and 44) are associated with differences in insulin sensitivity or beta cell function. The $G$ allele of SNP 43 was associated with a greater insulin response, possibly a compensatory response to decreased insulin sensitivity. Indeed, there was no difference between the groups, when insulin secretion was adjusted for insulin sensitivity. The TT genotype of SNP 44 was associated with impaired insulin-stimulated glucose uptake. Carriers of the risk-genotype combination
SNP44 TT and SNP43 GG showed the greatest reduction in insulin-stimulated glucose uptake (Fig. 7). The association between SNPs in the CAPN10 gene and insulin-stimulated glucose uptake are consistent with earlier data from our own group [26] and in Pima Indians [15], as well as in experimental animals [52], suggesting that variants in CAPN1O gene do in fact influence insulin sensitivity. The difference in insulin sensitivity was most obvious in subjects with normal glucose tolerance, whereas the difference disappeared in patients with Type 2 diabetes. This is not surprising, as secondary changes in insulin sensitivity probably dominate over genetic influences in patients with manifest diabetes. Although the mechanisms by which CAPN10 increases susceptibility to Type 2 diabetes are unknown, it is tempting to speculate that they would include changes in gene expression in both the muscle and the beta cells. In support of this, these variants in CAPN10 have been shown to cause a modest reduction in gene expression [15]. Our results differ from those of two recent studies, one from Scandinavia and the other from Japan. Both these studies were unable to demonstrate any association between risk haplotype combinations of SNP-43, -19, -63 and insulin resistance $[53,54]$. However, neither of them compared the genotype combinations of SNP-43 and $-44$.

Taken together our cross-sectional data show that defects in muscle, liver and islets occur in parallel and correlate with an increase in abdominal obesity and circulating NEFA concentrations. They thus support the hypothesis that peripheral and hepatic insulin resistance as well as beta cell dysfunction in Type 2 diabetes could be caused by similar defects. They further demonstrate that these defects are influenced by variations in the calpain-10 gene.

Acknowledgements. This study was financially supported by a JDF-Wallenberg Center of Excellence grant (JD-12812-01A), an EC grant (GIFT), as well as grants from the Swedish Medical Research Council, the Sigrid Juselius Foundation, the Swedish Diabetes Research Foundation and the Novo Nordisk Foundation. D. Tripathy and K. F. Eriksson contributed equally to this study. 


\section{Appendix}

Clinical characteristics of the 203 men from the different sixtiles of 2-hour glucose

\begin{tabular}{|c|c|c|c|c|c|c|}
\hline \multirow[b]{2}{*}{$\begin{array}{l}\text { 2-h glucose }(\mathrm{mmol} / \mathrm{l}) \\
\text { median [interquartile range] }\end{array}$} & \multicolumn{6}{|c|}{ Sixtiles 1 to 6 (left to right) } \\
\hline & $5.5[5.2-5.8]$ & $7.0[6.9-7.1]$ & $8.0[7.9-8.2]$ & $9.7[9.5-10.0]$ & 13.8 [13.2-14.5] & 20.9 [19.4-20.8] \\
\hline Age (years) & $65.9 \pm 0.6$ & $65.9 \pm 0.2$ & $65.8 \pm 0.3$ & $66.5 \pm 0.3$ & $66.1 \pm 0.3$ & $65.6 \pm 0.3$ \\
\hline BMI $\left(\mathrm{kg} / \mathrm{m}^{2}\right)$ & $25.0 \pm 0.5$ & $26.2 \pm 0.5$ & $27.7 \pm 0.6$ & $27.4 \pm 0.68$ & $28.1 \pm 0.6^{\mathrm{a}}$ & $27.2 \pm 0.7$ \\
\hline $\mathrm{WHR}^{\mathrm{b}}$ & $0.94 \pm 0.01$ & $0.97 \pm 0.01$ & $0.96 \pm 0.02$ & $0.97 \pm 0.02$ & $0.98 \pm 0.01^{\mathrm{a}}$ & $0.99 \pm 9.01^{\mathrm{a}}$ \\
\hline $\mathrm{HbA}_{1} \mathrm{c}(\%)$ & $4.8 \pm 0.2$ & $4.8 \pm 0.08$ & $4.8 \pm 0.07$ & $5.1 \pm 0.09^{a}$ & $6.3 \pm 0.1^{\mathrm{a}}$ & $8.1 \pm 0.3^{\mathrm{a}}$ \\
\hline Fasting insulin $(\mathrm{mU} / \mathrm{l})^{\mathrm{b}}$ & $8.3 \pm 1.0$ & $8.0 \pm 0.7$ & $14.2 \pm 1.5$ & $14.1 \pm 1.5$ & $18.7 \pm 2.9$ & $14.4 \pm 1.1$ \\
\hline 2-h insulin (mU/l) & $33.5 \pm 5.8$ & $54.3 \pm 4.9$ & $96.1 \pm 7.5$ & $95.1 \pm 8.4$ & $84.2 \pm 12.7$ & $27.7 \pm 2.9$ \\
\hline Cholesterol (mmol/l) & $5.41 \pm 0.1$ & $5.76 \pm 0.1$ & $5.5 \pm 0.1$ & $5.49 \pm 0.1$ & $5.85 \pm 0.2$ & $5.73 \pm 0.2$ \\
\hline HDL cholesterol (mmol/l) & $1.33 \pm 0.05$ & $1.24 \pm 0.05$ & $1.18 \pm 0.05$ & $1.19 \pm 0.04$ & $1.14 \pm 0.05$ & $1.04 \pm 0.05^{\mathrm{a}}$ \\
\hline Triglycerides $^{\mathrm{b}}(\mathrm{mmol} / \mathrm{l})$ & $1.08 \pm 0.05$ & $1.44 \pm 0.1$ & $1.45 \pm 0.01$ & $1.61 \pm 0.2$ & $2.19 \pm 0.3^{\mathrm{a}}$ & $2.46 \pm 0.3^{\mathrm{a}}$ \\
\hline
\end{tabular}

Data are means \pm SEM. ${ }^{\mathrm{a}} p<0.05$ vs lowest sixtile, ${ }^{\mathrm{b}} p<0.05$ for trend. $\mathrm{VO}_{2 \max }$, maximal aerobic capacity

\section{References}

1. Beck-Nielsen H, Groop LC (1994) Metabolic and genetic characterization of prediabetic states. Sequence of events leading to non-insulin-dependent diabetes mellitus. J Clin Invest 94:1714-1721

2. DeFronzo RA (1988) Lilly lecture 1987. The triumvirate: beta-cell, muscle, liver. A collusion responsible for NIDDM. Diabetes 37:667-687

3. Weyer C, Bogardus C, Mott DM, Pratley RE (1999) The natural history of insulin secretory dysfunction and insulin resistance in the pathogenesis of type 2 diabetes mellitus. J Clin Invest 104:787-794

4. Reaven GM, Hollenbeck CB, Chen YD (1989) Relationship between glucose tolerance, insulin secretion, and insulin action in non-obese individuals with varying degrees of glucose tolerance. Diabetologia 32:52-55

5. Bogardus C, Lillioja S, Howard BV, Reaven G, Mott D (1984) Relationships between insulin secretion, insulin action, and fasting plasma glucose concentration in nondiabetic and noninsulin-dependent diabetic subjects. J Clin Invest 74:1238-1246

6. Ferrannini E, Groop LC (1989) Hepatic glucose production in insulin-resistant states. Diabetes Metab Rev 5:711-726

7. Pigon J, Giacca A, Ostenson CG, Lam L, Vranic M, Efendic S (1996) Normal hepatic insulin sensitivity in lean, mild noninsulin-dependent diabetic patients. J Clin Endocrinol Metab 81:3702-3708

8. Jeng CY, Sheu WH, Fuh MM, Chen YD, Reaven GM (1994) Relationship between hepatic glucose production and fasting plasma glucose concentration in patients with NIDDM. Diabetes 43:1440-1444

9. Meyer C, Stumvoll M, Nadkarni V, Dostou J, Mitrakou A, Gerich J (1998) Abnormal renal and hepatic glucose metabolism in type 2 diabetes mellitus. J Clin Invest 102:619-624

10. Groop LC, Widen E, Ferrannini E (1993) Insulin resistance and insulin deficiency in the pathogenesis of type 2 (noninsulin-dependent) diabetes mellitus: errors of metabolism or of methods? Diabetologia 36:1326-1331
11. Kahn SE, Prigeon RL, McCulloch DK et al. (1993) Quantification of the relationship between insulin sensitivity and beta-cell function in human subjects. Evidence for a hyperbolic function. Diabetes 42:1663-1672

12. Eriksson KF, Lindgarde F (1991) Prevention of type 2 (non-insulin-dependent) diabetes mellitus by diet and physical exercise. The 6-year Malmo feasibility study. Diabetologia 34:891-898

13. Eriksson KF, Lindgarde F (1998) No excess 12-year mortality in men with impaired glucose tolerance who participated in the Malmo Preventive Trial with diet and exercise. Diabetologia 41:1010-1016

14. Horikawa Y, Oda N, Cox NJ et al. (2000) Genetic variation in the gene encoding calpain-10 is associated with type 2 diabetes mellitus. Nat Genet 26:163-175

15. Baier LJ, Permana PA, Yang X et al. (2000) A calpain-10 gene polymorphism is associated with reduced muscle mRNA levels and insulin resistance. J Clin Invest 106:R69-R73

16. WHO (1979) Classification and diagnosis of diabetes mellitus and other categories of glucose intolerance. National Diabetes Data Group. Diabetes 28:1039-1057

17. Alberti KG, Zimmet PZ (1998) Definition, diagnosis and classification of diabetes mellitus and its complications. Part 1: diagnosis and classification of diabetes mellitus provisional report of a WHO consultation. Diabet Med 15:539-553

18. Talluri T, Lietdke RJ, Evangelisti A, Talluri J, Maggia G (1999) Fat-free mass qualitative assessment with bioelectric impedance analysis (BIA). Ann NY Acad Sci 873:94-98

19. DeFronzo RA, Tobin JD, Andres R (1979) Glucose clamp technique: a method for quantifying insulin secretion and resistance. Am J Physiol 237:E214-E223

20. Hother-Nielsen O, Mengel A, Moller J, Rasmussen O, Schmitz O, Beck-Nielsen H (1992) Assessment of glucose turnover rates in euglycaemic clamp studies using primedconstant $\left[3-{ }^{3} \mathrm{H}\right]$-glucose infusion and labelled or unlabelled glucose infusates. Diabet Med 9:840-849 
21. Zambon A, Hashimoto SI, Brunzell JD (1993) Analysis of techniques to obtain plasma for measurement of levels of free fatty acids. J Lipid Res 34:1021-1028

22. Larsson H, Ahren B (1998) Glucose-dependent arginine stimulation test for characterization of islet function: studies on reproducibility and priming effect of arginine. Diabetologia 41:772-777

23. Ward WK, Bolgiano DC, McKnight B, Halter JB, Porte D Jr (1984) Diminished B cell secretory capacity in patients with noninsulin-dependent diabetes mellitus. J Clin Invest 74:1318-1328

24. Grill V (1981) Time and dose dependencies for priming effect of glucose on insulin secretion. Am J Physiol 240:E24-E31

25. Bergman RN, Phillips LS, Cobelli C (1981) Physiologic evaluation of factors controlling glucose tolerance in man: measurement of insulin sensitivity and beta-cell glucose sensitivity from the response to intravenous glucose. J Clin Invest 68:1456-1467

26. Orho-Melander M, Klannemark M, Svensson MK, Ridderstrale M, Lindgren CM, Groop L (2002) Variants in the calpain-10 gene predispose to insulin resistance and elevated free fatty acid levels. Diabetes 51:2658-2664

27. Evans DJ, Murray R, Kissebah AH (1984) Relationship between skeletal muscle insulin resistance, insulin-mediated glucose disposal, and insulin binding. Effects of obesity and body fat topography. J Clin Invest 74:1515-1525

28. Waldhausl W, Roden M (2000) The effects of free fatty acids on glucose transport and phosphorylation in human skeletal muscle. Curr Opin Endocrinol Diabetes 7:211-216

29. Baldeweg SE, Golay A, Natali A, Balkau B, Del Prato S, Coppack SW (2000) Insulin resistance, lipid and fatty acid concentrations in 867 healthy Europeans. European Group for the Study of Insulin Resistance (EGIR). Eur J Clin Invest 30:45-52

30. Laws A, Hoen HM, Selby JV, Saad MF, Haffner SM, Howard BV (1997) Differences in insulin suppression of free fatty acid levels by gender and glucose tolerance status. Relation to plasma triglyceride and apolipoprotein B concentrations. Insulin Resistance Atherosclerosis Study (IRAS) Investigators. Arterioscler Thromb Vasc Biol 17:64-71

31. Frayn KN (2002) Adipose tissue as a buffer for daily lipid flux. Diabetologia 45:1201-1210

32. Krssak M, Falk Petersen K, Dresner A et al. (1999) Intramyocellular lipid concentrations are correlated with insulin sensitivity in humans: a $1 \mathrm{H}$ NMR spectroscopy study. Diabetologia 42:113-116

33. Perseghin G, Scifo P, De Cobelli F et al. (1999) Intramyocellular triglyceride content is a determinant of in vivo insulin resistance in humans: $\mathrm{a}^{1} \mathrm{H}-{ }^{13} \mathrm{C}$ nuclear magnetic resonance spectroscopy assessment in offspring of type 2 diabetic parents. Diabetes 48:1600-1666

34. Jacob S, Machann J, Rett K et al. (1999) Association of increased intramyocellular lipid content with insulin resistance in lean nondiabetic offspring of type 2 diabetic subjects. Diabetes 48:1113-1119

35. Dresner A, Laurent D, Marcucci M et al. (1999) Effects of free fatty acids on glucose transport and IRS-1-associated phosphatidylinositol 3-kinase activity. J Clin Invest 103:253-259

36. Griffin ME, Marcucci MJ, Cline GW et al. (1999) Free fatty acid-induced insulin resistance is associated with activation of protein kinase $\mathrm{C}$ theta and alterations in the insulin signaling cascade. Diabetes 48:1270-1274

37. Cline GW, Petersen KF, Krssak M et al. (1999) Impaired glucose transport as a cause of decreased insulin-stimulated muscle glycogen synthesis in type 2 diabetes. $\mathrm{N}$ Engl $\mathrm{J}$ Med 341:240-246

38. Meyer C, Dostou J, Nadkarni V, Gerich J (1998) Effects of physiological hyperinsulinemia on systemic, renal, and hepatic substrate metabolism. Am J Physiol 275:F915-F921

39. Seppala-Lindroos A, Vehkavaara S, Hakkinen AM et al. (2002) Fat accumulation in the liver is associated with defects in insulin suppression of glucose production and serum free fatty acids independent of obesity in normal men. J Clin Endocrinol Metab 87:3023-3028

40. Lewis GF, Carpentier A, Adeli K, Giacca A (2002) Disordered fat storage and mobilization in the pathogenesis of insulin resistance and type 2 diabetes. Endocr Rev 23:201-229

41. Hennes MM, Dua A, Kissebah AH (1997) Effects of free fatty acids and glucose on splanchnic insulin dynamics. Diabetes 46:57-62

42. Svedberg J, Stromblad G, Wirth A, Smith U, Bjorntorp P (1991) Fatty acids in the portal vein of the rat regulate hepatic insulin clearance. J Clin Invest 88:2054-2058

43. Bavenholm PN, Pigon J, Ostenson CG, Efendic S (2001) Insulin sensitivity of suppression of endogenous glucose production is the single most important determinant of glucose tolerance. Diabetes 50:1449-1454

44. Tripathy D, Carlsson AL, Lehto M, Isomaa B, Tuomi T, Groop L (2000) Insulin secretion and insulin sensitivity in diabetic subgroups: studies in the prediabetic and diabetic state. Diabetologia 43:1476-1483

45. McGarry JD (2002) Banting lecture 2001: dysregulation of fatty acid metabolism in the etiology of type 2 diabetes. Diabetes 51:7-18

46. Shimabukuro M, Zhou YT, Lee Y, Unger RH (1998) Troglitazone lowers islet fat and restores beta cell function of Zucker diabetic fatty rats. J Biol Chem 273:3547-3 550

47. Pipeleers D, Hoorens A, Marichal-Pipeleers M, Van de Casteele M, Bouwens L, Ling Z (2001) Role of pancreatic beta-cells in the process of beta-cell death. Diabetes 50 [Suppl 1]:S52-S57

48. Mulder H, Holst LS, Svensson H et al. (1999) Hormonesensitive lipase, the rate-limiting enzyme in triglyceride hydrolysis, is expressed and active in beta-cells. Diabetes 48:228-232

49. Harndahl L, Jing XJ, Ivarsson R et al. (2002) Important role of phosphodiesterase $3 \mathrm{~B}$ for the stimulatory action of cAMP on pancreatic beta-cell exocytosis and release of insulin. J Biol Chem 277:37446-37455

50. Evans JC, Frayling TM, Cassell PG et al. (2001) Studies of association between the gene for calpain-10 and type 2 diabetes mellitus in the United Kingdom. Am J Hum Genet 69:544-552

51. Garant MJ, Kao WH, Brancati F et al. (2002) SNP43 of CAPN10 and the risk of type 2 diabetes in African-Americans: the Atherosclerosis Risk in Communities Study. Diabetes 51:231-237

52. Sreenan SK, Zhou YP, Otani K et al. (2001) Calpains play a role in insulin secretion and action. Diabetes 50:20132020

53. Rasmussen SK, Urhammer SA, Berglund L et al. (2002) Variants within the calpain-10 gene on chromosome $2 q 37$ (NIDDM1) and relationships to type 2 diabetes, insulin resistance, and impaired acute insulin secretion among Scandinavian Caucasians. Diabetes 51:3561-3567

54. Horikawa Y, Oda N, Yu L et al. (2003) Genetic variations in calpain-10 gene are not a major factor in the occurrence of type 2 diabetes in Japanese. J Clin Endocrinol Metab $88: 244-247$ 